\title{
The Impact of Power and Ideology on Edward FitzGerald's Translation of the Rubáiyát: A Postcolonial Approach
}

\author{
Bentolhoda Nakhaei
}

University of Lorraine

This paper analyzes the issues raised by the change of ideology and the underlying meanings in five FitzGerald's translations of Khayyám's quatrains according to the theories of certain translation scholars such as André Lefevere and Antoine Berman. With regard to the fact that the British translator has given a harmonizing beauty and an epicurean flavor of his own to Khayyám's Rubáiyát, could it be claimed that translator's voice is louder than the author's? From the transcreation point of view, one could wonder whether FitzGerald did maintain the intent, style, tone, and content of the Persian quatrains. Do FitzGerald's translations evoke the same emotions and does it carry the same implications in English as Khayyám's Rubáiyát does in Persian. In general, from a postcolonial perspective, FitzGerald's five English translations could offer interesting and fertile ground for investigating the effects of power relationship between the colonizer and the colonized text during the Victorian age in England.

Keywords: Khayyám, quatrains, English translations, the colonizer, the colonized text. 